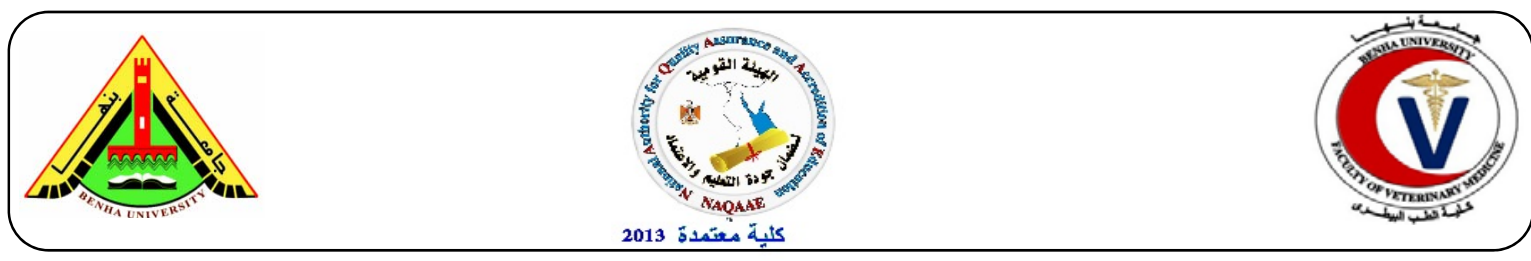

\title{
Detection of Rota and Corona viral antigens in diarrheic newly born calves in Menofiya governorate.
}

Khamees, A.K.S.

Animal Health Research Institute, Shebin El Kom branch

\section{A B S T R A C T}

The present study was carried out to determine the prevalence of Rota and Corona viruses infection among newly born calves in Menofiya governorate during the period from November 2014 to March 2015. Two hundreds diarrhoeic stool samples were collected directly from newly born calves (aged from 1 to 30 days) in different localities of Menofiya governorate and were screened for Rota and corona viruses using direct sandwich ELISA. The samples were grouped according to the age of the calves into 3 age groups as follows: $1^{\text {st }}$ age group (1-10 days), $2^{\text {nd }}$ age group (11-20 days) and $3^{\text {rd }}$ age group (21-30 days). Out of examined samples, were $87(43.5 \%)$ positive for presence of Rotavirus antigen and 51 (25.5\%) for coronavirus antigen; whereas $12(6 \%)$ samples were positive for both viruses (mixed infection). Rotavirus was found in high prevalence in the $1^{\text {st }}$ age group $(60.8 \%)$ whereas Coronavirus was found in high prevalence in the $3^{\text {rd }}$ age group $(48.2 \%)$. Both viruses were found in the $2^{\text {nd }}$ age group where the incidence of Rota was $40 \%$ and Corona was $26.2 \%$. Indeed, the study reports the circulation of Rota and Corona viruses associating with diarrhea in newly born calves in the area of investigation.

Keywords: Bovine corona virus; Rota virus; calf Diarrhoea and ELISA.

(http://www.bvmj.bu.edu.eg)

(BVMJ-29(1): 9-16, 2015)

\section{INTRODUCTION}

$\mathrm{N}$ ewly born calves represent an important source of animal production for either meat or breeding world wide (Radostits et al., 2007 and Lorenz et al., 2011). Diarrhea is one of the very common disease syndromes in the neonatal calves in different countries and this can have severe impacts both economically and in terms of animal welfare (Özkan et al., 2011 and Tajik et al., 2012). Neonatal calf diarrhoea is a multifactorial disease, which despite decades of research in the topics remains the most common cause of mortality in calves less than one month of age (Heinrichs and Radostits 2001 and Alfieri et al., 2006). It has a complex etiology, but bovine Rota and Corona viruses have been found to be the most common causative agents (Gulliksen et al., 2009; Izzo et al., 2011 and Ammar et al., 2014). Rota virus belongs to the family Reoviridae, subfamily Sedoreoviridae and genus Rotavirus where the genus Rotavirus include five different species, Rotavirus A$\mathrm{E}$, the virus has a "wheel-like" appearance which explains the origin of its name. The virion has a diameter of $100 \mathrm{~nm}$ and consists of a triple layer capsid covering the genome. The genome consists of 11 segments of double stranded RNA (dsRNA) averaging $18,550 \mathrm{bp}$ with segments at a varying size between 663 and 3302 bp. (International Committee on Taxonomy of Viruses (ICTV), 2011; matthijnssens et al., 2011 and ICTV and King 2012). Corona virus belongs to family Coronoviridae subfamily Coronavirinae, genus Betacoronavirus. Coronavirus particles are irregularly shaped, $80-220 \mathrm{~nm}$ in diameter, with an outer envelope bearing distinctive, 'club- 
shaped' peplomers (20 nm long). This 'crown- like' appearance (Latin, corona) gives the family its name. It contains nonsegmented, positive sense and singlestranded RNA (Lai and Holmes 2001; ICTV, 2011 and ICTV and King 2012). Rota virus infection often occurs as early as the first week of life, while corona virus infection usually in the 2 nd or 3 rd week of life. In many cases, both types of viruses are involved in the disease process (Bazeley et al., 2003 and Langoni et al., 2004). Viral transmission can be through aerosols of respiratory secretions, via the fecal-oral route, or by mechanical transmission (Cho et al., 2000; Dash et al., 2012). ELISA is one of the essential methods in the determination of viral antigens. It is used widely in calves with diarrhea in feces for determination of Rota and Corona viruses (Badiei et al., 2010, Robaiee and AlFarwachi, 2013 and El-Bagoury et al., 2014). ELISA had the advantage of being inexpensive for examination of many samples and has the probability of being much more sensitive (Duman and Aycan, 2010 and Jakobsson, 2013). Early and confirmatory diagnosis of etiological agents responsible for calf diarrhoea helps in timely follow up of appropriate prevention and control measures, which could prevent the great economic losses to farmers and the dairy industry. In Menofiya governorate, there is no comprehensive information is available on the prevalence of infectious causes of neonatal diarrhoea, though few reports are available on individual pathogens responsible for calf diarrhoea. Therefore, the present study was carried out to investigate the prevalence of Rotavirus and Coronavirus responsible for causing neonatal calf diarrhoea in newly born calves in Menofiya governorate, Egypt during the period from November 2014 to march 2015.

\section{MATERIALS AND METHODS.}

\subsection{Collection of feces.}

During the period from November 2014 to March 2015, 200 fecal samples (collected directly from the rectum in sterile plastic bottles) were collected from local, nontreated neonatal calves (1-30 days old, showed variable degrees of diarrhea, which varied from mild to profuse watery feces. Its color varied from whitish yellow to greenish color. In some cases, tinged with blood or mucus) that were randomly selected from field cases in different localities in Menofiya governorate, Egypt as illustrated in table (1), the examined calves were classified according to their ages into 3 groups: $1^{\text {st }}$ group of age (1-10 days), $2^{\text {nd }}$ group of age (11-20 days) and $3^{\text {rd }}$ group of age (21-30 days). The samples were transported in ice and stored at $-20^{\circ} \mathrm{C}$ till analyzing. Fecal samples were diluted and prepared according to manufacture of utilized Kit.

\subsection{Detection of Rotavirus.}

The fecal samples were tested for the presence of Rota viral antigen by using direct Sandwich ELISA. It was performed as described by the kit manufacturer (Rota virus ELISA kit, Bio-X Diagnostics, Belgium).

\subsection{Detection of Coronavirus.}

All fecal samples were analyzed using commercial ELISA kits (Corona virus ELISA kit, Bio-x Diagnostic, Belgium) according to manufacture instructions for detection of corona viral antigen.

\section{RESULTS.}

Rotavirus antigen was detected in 87 faecal samples (43.5\%) of 200 diarrheic calves as shown in table (2). By using direct sandwich ELISA kit for detection of Coronavirus antigen, we found that 51 faecal samples $(25.5 \%)$ out of 200 examined fecal samples were positive as shown in table (3). Results in table (4) revealed that regarding age-group in this study, the frequency of infection by rotavirus is higher in $1^{\text {st }}$ age-group, $1-10 \mathrm{~d}$, $48(60.8 \%)$. 
Table 1: Distribution of clinically examined calves in relation to the localities in Menofiya governorate and the calves' age.

\begin{tabular}{|c|c|c|c|c|}
\hline \multirow[t]{2}{*}{ Locality } & \multicolumn{3}{|c|}{ Age group } & \multirow{2}{*}{$\begin{array}{l}\text { Total number of examined calves } \\
\text { (No of collected samples) }\end{array}$} \\
\hline & $1^{\text {st }}$ group & $2^{\text {nd }}$ group & $3^{\text {rd }}$ group & \\
\hline Ashmoun & 10 & 7 & 7 & 24 \\
\hline Berket El Sabea & 9 & 8 & 6 & 23 \\
\hline El Bagour & 9 & 6 & 7 & 22 \\
\hline El Saddat & 10 & 8 & 6 & 24 \\
\hline El Shohadaa & 8 & 7 & 5 & 20 \\
\hline Tala & 8 & 7 & 6 & 21 \\
\hline Qwesna & 9 & 7 & 8 & 24 \\
\hline Shebin El Kom & 8 & 8 & 4 & 20 \\
\hline Menouf & 8 & 7 & 7 & 22 \\
\hline Total & 79 & 65 & 56 & 200 \\
\hline
\end{tabular}

$1^{\text {st }}$ group: calves aged 1-10 days. $2^{\text {nd }}$ group: calves aged 11- 20 days. $\quad 3^{\text {rd }}$ group: calves aged 21- 30 days.

Table 2: Results of direct sandwich ELISA for detection of Rotavirus Antigen in feces of diarrheic calves.
No. of examined fecal samples
No. of +ve Samples
$\%$ of + ve samples

200

87

43.5

Table 3: Results of direct sandwich ELISA for detection of Coronavirus Antigen in feces of diarrheic calves.

\begin{tabular}{ccc}
\hline No. of examined fecal samples & No. of +ve Samples & $\%$ of +ve samples \\
\hline 200 & 51 & 25.5 \\
\hline
\end{tabular}

Table 4: Incidence of Rota and Corona Viruses at different age group in Menofiya governorate using sandwich ELISA.

\begin{tabular}{lccccccccc}
\hline Age group & $\begin{array}{c}\text { No. of } \\
\text { examined } \\
\text { fecal } \\
\text { samples }\end{array}$ & Rota virus & Corona virus & $\begin{array}{c}\text { Mixed Rota } \\
\text { and Corona } \\
\text { viruses }\end{array}$ & \multicolumn{2}{c}{$\begin{array}{c}\text { negative } \\
\text { samples }\end{array}$} \\
\cline { 3 - 10 } & & No. & $\%$ & No. & $\%$ & No. & $\%$ & No. & $\%$ \\
\hline $1^{\text {st }}$ age group \\
$\begin{array}{l}(1-10 \text { days }) \\
2^{\text {nd }} \text { age group }\end{array}$ & 79 & 48 & 60.8 & 7 & 8.7 & 3 & 3.8 & 27 & 34.2 \\
$\begin{array}{l}(11-20 \text { days }) \\
3^{\text {rd }} \text { age group }\end{array}$ & 65 & 26 & 40.0 & 17 & 26.2 & 7 & 10.8 & 29 & 44.6 \\
$(21-30$ days $)$ & 56 & 13 & 23.2 & 27 & 48.2 & 2 & 3.6 & 18 & 32.1 \\
Total & 200 & 87 & 43.5 & 51 & 25.5 & 12 & 6 & 74 & 37 \\
\hline
\end{tabular}




\section{DISCUSSION}

This paper aimed to study the incidence of Rotavirus and Coronavirus in fecal samples collected from different localities covering Menofiya governorate, Egypt during the period from November 2014 to March 2015 using direct sandwich ELISA for antigen detection of both viruses. The highest rates of diarrhea were observed in $1^{\text {st }}$ group, followed by $2^{\text {nd }}$ group, then $3^{\text {rd }}$ group as shown in table (1). this observation was reported by others, (Lorino et al., (2005) ; El-Naker et al., (2007) and Lorenz et al., (2011)), who reported that the incidence rate of diarrhea during neonatal period was high in the first days of calves' age. Rota and coronavirus are ubiquitous and as a result, most of the animals, including pregnant cows coming from intensive livestock farms, have specific antibodies against these pathogens. The antibodies produced by cows in response to natural immunization or vaccination are transmitted to the calf at birth via the colostrum (Radostits et al., 2007 and Morshedi et al., 2010), so the diagnosis of Rota and Corona viruses infection has been based primarily on the detection of virus or viral antigen in the feces. There are a variety of diagnostic methods available for the detection of rotavirus and coronavirus including PCR, ELISA, Electron microscope and Immune electron microscope (Cho et al., 2010 and Jakobsson 2013). ELISA is one of the essential methods in the determination of viral antigens and has the good qualities of being fast and having the capability to handle a big number of samples at the same time (Duman and Aycan 2010 and Jakobsson 2013). It is used widely in calves with diarrhea in faeces for determination of Rota and Corona viral antigens (Ali et al., 2008; Dhama et al., 2009, Badiei et al., 2010 and El-Bagoury et al., 2014). Rotavirus transmits through a fecal-oral route and calves are most often infected by contact with other calves, primarily or secondary through objects, feed and water. It has been proposed that calves can also be infected by virus shed by the dam at birth. The infected calves shed virus through the feces from the second day of infection and the shedding may last for 7-8 days. (Malik et al., 2005 ; Dhama et al., 2009; Suresh et al., 2013 and Collins et al., 2014). By using direct sandwich ELISA kit for detection of Coronavirus antigen, 51 faecal samples $(25.5 \%)$ out of examined fecal samples (200) were positive as shown in table (3). This result may be related to virus shedding in outbreaks in non vaccinated populations of calves ( Brandão et al., 2007 ; Oliveira Filho et al., 2007 and Gay et al., 2012). Depending on the age of the calf, some pathogens are more likely to be the cause of diarrhea; Corona and rotavirus most commonly affect calves aged 5-20 days old although it can affect calves up to several months of age (Reidy et al., 2006; Dash et al., 2011 and Gay et al., 2012). Results in table (4) revealed that regarding age-group in this study, the frequency of infection by rotavirus is higher in $1^{\text {st }}$ age-group, $1-10 \mathrm{~d}$, $48(60.8 \%)$, this age bracket is considered as the most susceptible to infection by rotavirus (Alfieri et al., 2006 ; Dhama et al., 2009 and Collins et al., 2014). While the frequency of infection by Coronavirus is higher in $3^{\text {rd }}$ age-group, $21-30 \mathrm{~d}, 27$ $(48.2 \%)$, this age bracket is reported as the most susceptible to infection by Coronavirus (Brandão et al., 2007 ; Stipp et al., 2009 and Izzo et al., 2011). In the $2^{\text {nd }}$ age-group, 11-20 d, the incidence of Rotavirus and Coronavirus infection were $26(40.0 \%), 17$ (26.2\%) respectively, which may be due to decreasing of passive immunity and the absence of the natural resistance against infection for both enteropathogens (Steele et al., 2004 ; Uhde et al., 2008 and Ammar et al., 2014). The presence of Coronavirus infection in older calves (21-30 d) could be explained by the method of livestock farming of calves (using the grouping of the calves instead of individual stall). The 3-weeks-old calves are characterized by decrease of rotavirus, this may be highlighted by an increased 
natural resistance against infection for this enteropathogen (Gumusova et al., 2007; Suresh et al., 2013 and Ammar et al., 2014). The mixed infection of Rotavirus and Coronavirus in $12(6 \%)$ of the examined calves (table 4) demonstrates that infection, with both viruses is possible and not rare, even though they infect the same portion of the small intestine, i.e. jejunum and ileum, Considering the high rate of diagnosis in outbreaks of neonatal calf diarrhea, all diarrheic stool samples screened for enteric pathogens must be tested for both Rotavirus and Coronavirus. This strategy will shed new light on the causes of calf diarrhea outbreaks involving vaccinated beef and dairy cattle herds and outbreaks with severe clinical signs and higher morbidity and mortality rates (Jerez et al., 2002; Alfieri et al., 2006; Oliveira Filho et al., 2007 and Barry et al., 2009). Negative results in 74 $(37 \%)$ of tested samples (table 4 ) may occur because some cases of diarrhea might not be associated with infectious agents, and probably due to nutritional or other management factors, or because other noninvestigated pathogens were involved, such as many other enteric bacterial (E. coli F5 and other enteropathogenic E. coli, and Campylobacter etc.), parasite (Cryptosporidium parvum) (Heinrichs and Radostits 2001; Scott et al., 2004; Alfieri et al., 2006; Gulliksen et al., 2009). The results indicated the role of rotavirus and coronavirus as a serious cause of neonatal calf diarrhea. Further studies are needed to understand the dynamics of these viruses transmission, cycle, and to identify alternative management practices to minimize the risk to animals. In conclusion, identification of causative agents adds to the epidemiol-ogical data regarding important infectious pathogens responsible for calf diarrhoea. It is difficult to control calf mortality due to unorganized rearing of dairy animals. Prevalence studies will help to devise suitable approach for the control of calf diarrhoea and appropriate advice on colostrum feeding, calf nutrition, hygiene and therapeutic regimens can be given. In addition, in future, vaccination strategy for neonatal calf diarrhoea could be designed, which is not currently practiced in El Menofiya Governorate. In calf diarrhoea, apart from clinical signs, laboratory detection of etiological agent is necessary to reach the conclusive diagnosis.

\section{REFERENCES}

Ali, Y.H., Khalafalla, A.I., Gaffar, M.E., Peenz, I. and Steel, A.D. 2008. Detection and isolation of group A rotavirus from camel calves in Sudan. Vet. Arhiv. 78:477-485.

Alfieri, A.A, Parazzi, M.E., Takiuchi, E., Medici, K.C., Alfieri, A.F. 2006. Frequency of group A rotavirus in diarrhoeic calves in Brazilian cattle herds, 1998-2002. Trop Anim Health Prod, 38:521-526.

Ammar, S., Mokhtaria, K., Tahar, B., Amar, A., Redha, B., Yuva, B., Mohamed, H., Abdellatif, N. and Laid, B. 2014: Prevalence of rotavirus (GARV) and coronavirus $(\mathrm{BCoV})$ associated with neonatal diarrhea in calves in western Algeria Asian Pac J Trop Biomed, 4(1):S318-S322.

Badiei, K., Pourjafar, M. and Ghane, M. 2010. Fecal rotavirus antigen in diarrheic calves of high and average producing Holstein dairy cows. Global Veterinaria, 5(3):175-197.

Barry, A.F., Alfieri, A. F., Stipp, D., Alfieri, A.A. 2009. Bovine Coronavirus Detection in a Collection of Diarrheic Stool Samples Positive for Group A Bovine Rotavirus. 52, Special Number: pp. 45-49.

Bazeley, H.M., Unver, A., Gunes, V., Citil, M. 2003. Frequency of rotavirus and corona virus in neonatal calves in kars. District. Kafkas-Universites Veteriner- Fakultesi Dergisi 9(1): 6568.

Brandão, P.E., Villareal, L.Y., De Souza, S.L., Richtzenhain, L.J., Jerez, J.A. 2007. Mixed infections by bovine coronavirus, rotavirus and 
Cryptosporidium parvum in an outbreak of neonatal diarrhea in beef cattle. Arq Inst Biol (Sao Paulo), 74:33-34.

Cho, K.O., Halbur, P.G., Bruna, J.D. 2000. Detection and isolation of coronavirus from feces of three herds of feedlot cattle during outbreaks of winter dysentery like disease. J. Am. Vet. Med. Assoc. 217:1191-1194.

Cho, Y.I., Kim, W.I., Liu, S. Kinyon, J.M., Yoon, KJ. 2010. Development of a panel of multiplex real-time polymerase chain reaction assays for simultaneous detection of major agents causing calf diarrhea in feces. J Vet Diagn Invest, 22:509-517.

Collins, P., Mulherin, E., Cashman, O., Lennon, G., Gunn, L., O'Shea, H. and Fanning, S. 2014: Detection and characterization of bovine rotavirus in Ireland from 2006-2008. Irish Veterinary Journal, 67:13.

Dash SK, Tewari A, Krishna Kumar, Goel Aand Bhatia AK 2011: Detection of rotavirus from diarrhoeic cow calves in Mathura, India. Vet. World 4 (12):554-556.

Dash S. K., Kumar, K., Goel A. and Bhatia K. 2012. Detection of Corona virus antigen by ELISA from diarrhoeic cow calves in Mathura, India. Vet. World, 5(3):166-168.

Dhama, K., Chauhan, R.S., Mahendran, M. and Malik, S.V. 2009: Rotavirus diarrhea in bovines and other domestic animals. Vet. Res. Commun, 33(1):1-23.

Duman, R. and Aycan, A. E. 2010: Prevalence of rotavirus infection in calves with diarrhea in Konya region. J. Anim. Vet. Adv., 9(1):136-138.

El-Bagoury, G.F., El-Nahas, E. M., Sharaf El-Deen, S.S., Salem, S.A.H. 2014. Frequency of Rotavirus detection by a sandwitch ELISA in faeces of diarrheic bovine calves from Qalubia province, Egypt. BVMJ, 27(2):341347.
El-Naker, Y., El- Sawalhy, A., Youssef, M. and Zeidan, S. 2007. Some studies on neonatal calf diarrhea in Egypt, Part 1: Causative agents and some epidemiological aspects Bull. Anim. Hlth. Prod. Afr., 56:161 - 190.

Gay, C.C., Hodgson, J.C., Lofstedt, J. and Bolin, S.R. 2012. Diarrhea in neonatal ruminants: intestinal diseases in ruminants: Merck Veterinary Manual. (Online) available from Http://www. merckmanuals.com/vet/print// digestive_system/intestinal_diseases in_ruminants/diarrhea_in_neonatal_ ruminants.html.

Gulliksen, S.M., Jor, E., Lie, K.I., Hamnes, I.S., Loken, T., Akerstedt, J., et al. 2009. Enteropathogens and risk factors for diarrhea in Norwegian dairy calves. J Dairy Sci., 92:50575066.

Gumusova, S.O., Yazici, Z., Albayrak, H. and Meral, Y. 2007. Rotavirus and coronavirus prevalence in healthy calves and calves with diarrhea. Medycnya Weterinaria, 63:62-64.

Heinrichs, A.J. and Radostits, O. 2001. Health and Production Management of Dairy Calves and Replacement Heifers. In: Radostits, O.M. (Ed.): Herd Health. Food Animal Production Medicine. 3rd Ed., Saunders Company, USA. pp. 333395.

International Committee on Taxonomy of Viruses (ICTV) 2011. Available from: http://www.ictvonline.ORG/ virus taxonomy.ASP? Version=2011. Agricultura, M.D. [online] available from: http://www.Agricultura. GOV.BR/animal/ especies/bovinose-bubalinos. [Accessed 12-05].

International Committee on Taxonomy of Viruses (ICTV) and King, A.M.Q. 2012. Virus taxonomy: classification and nomenclature of viruses: Ninth, report of the International Committee on Taxonomy of viruses. London: Academic Press. (Immunology and microbiology 2011. 
Izzo MM, PD Kirkland, VL Mohler, NR Perkins, AA Gunn and JK Housea, 2011: Prevalence of major enteric pathogens in Australian dairy calves with diarrhoea. Aust Vet J, 89:167173.

Jakobsson, S. 2013. Diagnosis and Molecular Epidemiology of Bovine Rotavirus and Coronavirus in Brazil. Degree project within the Veterinary Medicine Program ISSN 1652-8697 Examensarbete, 22.

Jerez, J.A., Brandão, P.E., Buzinaro, M.G., Gregori, F., Rosales, C.A.R., Ito, F. H., Sakai, T. 2002. Detecção de rotavírus e coronavírus em fezes de bezerros neonatos com diarréia criados em vários municípios do estado de São Paulo, Brasil. Arq Inst Biol, 69:19-23.

Lai, M. and Holmes, K. 2001. Coronaviridae, the viruses and their replication, p. 1163-1185. In DM Knipe, PM Howley, DE Griffin, MA Martin, RA Lamb, B. Roziman and SE Strauss (ed), Fields virology, 4th ed, Lippincott Williams \& Wilkins, Philadelphia.

Langoni, H. Helio, Antonoio, C.L., Fernando, A., Aristeu, V. and Acacia, O.E. 2004. Contribution to the study of diarrhea etiology in neonate dairy calves in Saopawlo, Barasil. Braz. J. Vet. Res. Anim. Sci., 41(5)

Lorenz, I., Fagan, J. and More, S.J. 2011: calf health from birth to weaning. II. Management of diarrhea in preweaned calves. Ir. Vet. J. 64(1):9.

Lorino, T., Daudin, J.J., Robin, S., Sanaa, M. 2005. Factors associated with time to neonatal diarrhoea in French beef calves. Prev Vet Med; 68:91-102.

Malik, S.V.S., Barbuddhe, S.B., Rawool, D.B., Vaidya, V.M. and Sahare, A.M. 2005. Data sheet on Rotaviruses (Global status of Rotavirus infections in man and animals).In Animal Health and Reproduction Compentium, CAB International, Wallingford, UK.
Matthijnssens, J., Ciarlet, M., Mcdonald, S.M., Attoui, H., Banyai, K., Brister, J.R., Buesa, J., Esona, M.D., Estes, M.K., Gentsch, J.R., Iturriza-Gomara, M., Johne, R., Kirkwood, C.D., Martella, V., Mertens, P.P., Nakagomi, O., Parreno, V., Rahman, M., Ruggri, F.M., Saif, L.J., Santos, N., Steyer, A., Taniguchi, K., Patto, J.T., Desselberger, U. \& Vanranst, M. 2011. Uniformity of rotavirus strain nomenculture proposed by the rotavirus classification-working group. Arch. Virol. 156(8):1397-413.

Morshedi, A., Rabbani, M., Zahraei Salehi, T., Rezazadeh, F. and TaghipoorBazargani, T. 2010: Evaluation of antibodies levels against rotavirus and coronavirus in the colostrum of nonvaccinated cows in southern Tehran Iran. Int. J. Vet. Res., 4(4):217-219.

Oliveira Filho, J.P., Silva, D.P.G., Pacheco, M.D., Mascarini, L.M., Ribeiro, M. G. et al., 2007. Diarrhea in Nelore calves: Clinical and etiologic study. Braz J Vet Res, 27:419-424.

Özkan, C., N. Altuğ, N. Yüksek, A. Kaya, and Y. Akgül, 2011. Assessment of electrocardiographic findings, serum nitric oxide, cardiac troponins and some enzymes in calves with hyperkaliemia related to neonatal diarrhoea. Revue Méd Vét, 162:171176.

Radostits, O.M.; Gay, C.C.; Hichcliff, K.W. and Constable, P.D. 2007. Veterinary medicine, $10^{\text {th }}$ edition. WB Saunders Co., London, UK. pp: 851-875 and 1286-1305.

Reidy, N., Lennon, G., Fanning, S., Power, E., O'Shea, H. 2006. Molecular characterization and analysis of bovine rotavirus strains circulating in Ireland 2002-2004. Vet Microbiol 117:242-247.

Robaiee, A. and Al- Farwachi, M.I. 2013. Prevalence of rotaviral infection in diarrheic neonatal calves in Mosul city, Iraq. doi: 10. 5455 / vetworld. 538-540. 
Scott, P.R., Hall, G.A., Jones, P.W., Morgan, J.H. Calf Diarrhoea. In: Andrews AH, Blowey RW, Boyd H, Eddy RG, editors 2004: Bovin medicine diseases and husbandry of cattle. Oxford: Wiley- Blackwell, pp. 185-214.

Steele, A.D., Geyer, A. and Gerdes, G.H. 2004. Rotavirus infections. In: Coetzer JAW, Tustin RC (Eds), Infectious disease of livestock, Oxford University press, Southern Africa, 1256-1264.

Stipp, D.T., Barry, A.F., Alfieri, A.F., Takiuchi, E., Amude, A.M., Alfieri, A.A. 2009. Frequency of $\mathrm{BCoV}$ detection by a semi-nested PCR assays in faeces of calves from Brazilian cattle herds. Trop Anim Health Prod, 41:1563-1567.

Suresh, T., Rai, R.B., Wani, M.Y., Damodaran, T. and Dhama, K. 2013. detection of bovine rotavirus in neonatal calf diarrhoea by ELISA, FAT and transmission electron microscopy. International Journal of Current Research 5(7):1935-1939.

Tajik, J., Nazifi, S., Naghib, S.M. and Ghasrodasht, A.R. 2012. Comparison of electrocardiographic parameters and serum electrolytes and microelements between single infection of rotavirus and coronavirus and concurrent infection of Cryptosporidium parvum with rotavirus and coronavirus in diarrheic dairy calves. Comp Clin Pathol, 21: 241-244.

Uhde, F.L., Kaufmann, T., Sager, H., Albini, S., Zanoni, R., Schelling, E., Meylan, M. 2008. Prevalence of four enteropathogens in the faeces of young diarrhoeic dairy calves in Switzerland. Vet Rec, 163:362-366. 